\title{
'DIAGNOSING' STATELESSNESS AND EVERYDAY STATE ILLEGIBILITY IN NORTHERN THAILAND
}

\author{
JANEPICHA CHEVA-ISARAKUL*
}

\begin{abstract}
Statelessness in Thailand is primarily framed first and foremost as an issue of legibility to the state, with an assumption that once a stateless person is 'properly seen', due recognition will follow. This article builds on a growing body of literature that examines the limits of evidentiary approach and the burden of proving citizenship as experienced by many stateless persons around the world. I use the anthropological framework of 'state illegibility' to encapsulate the systemic violence and burden placed on stateless persons by the state's opaqueness and inscrutable, contradictory and unpredictable bureaucratic practices. Through three ethnographic accounts in Thailand, I interrogate various forms of state illegibility and their implications. I argue that by not recognising state illegibility, statelessness risks being reduced to an individualised legal status issue, rather than being acknowledged as a symptom of systemic discrimination.
\end{abstract}

\section{TABLE OF CONTENTS}

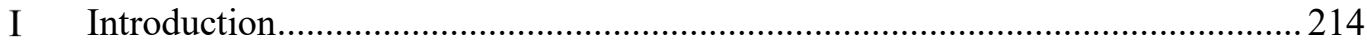

II Notes on Methodology and Positionality ............................................................2217

III Background on Statelessness in Thailand........................................................2218

IV Legibility Tools and Technology of Governing ...............................................222

V Expanding Rights of Stateless Persons and Continual Grey Areas ......................222

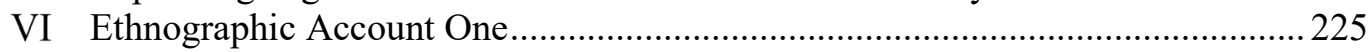

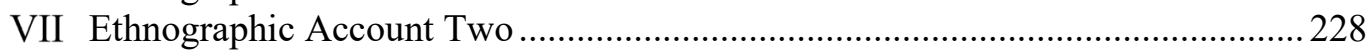

VIII Ethnographic Account Three: Reconciling Identities, January 2018_..................... 230

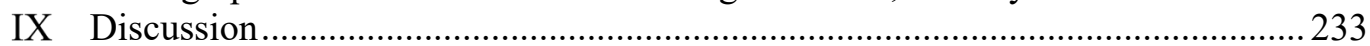

A Stereotyping and the Limits of an Individual Identity................................ 233

B State Illegibility through Documentary Practices.................................... 235

X State Illegibililty and the Framework of Exception...............................................2236

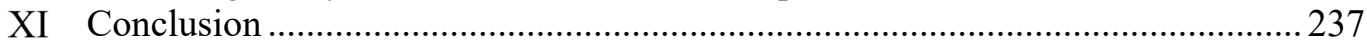

\section{INTRODUCTION}

There are people who have been living in Thailand for a long time but are not Thai. That is, they are not considered authentic Thai. Although they were born and bred in Thailand, they do not get the benefits of being Thai. This [treatment] has to be standardised because if there are people living in Thailand who feel left out and uncared for, this will diminish the national security.

— King Bhumibol at Klai Kangwon Palace in 2001. ${ }^{1}$

* Janepicha Cheva-Isarakul is a lecturer at the School of Social and Cultural Studies, Victoria University of Wellington, New Zealand. The author would like to acknowledge her participants and the stateless communities whose life stories appear in this article. Her sincere gratitude is also extended to the members of the Thailand's National Human Rights Council Sub-Committee on Indigenous and Minority Rights for allowing her to accompany them on their visit to the communities. She also is grateful for the constructive comments by the reviewers and for the helpful contribution of Ms Bongkot Napaumporn.

1 Ministry of Interior, Practicing Diagnosing and Addressing Issues of Legal status and
Citizenship
(Report,
12
May
2016)

$<$ www.bora.dopa.go.th/nationclinic/images/document/Citizenshipdiagnostics.pdf>. 
Commonly deemed the 'father of the country', King Bhumibol's call for inclusion and standardised treatment toward the non-citizen 'Other' holds a legitimising effect for those mobilising for the citizenship rights of stateless persons in Thailand. The very same quote also reflects a common view among the Thai policymakers that statelessness is not only a problem of individual human security but that of national security. The late King's words were referenced in an official letter issued by the Ministry of Interior on 12 May $2016 .{ }^{2}$ Classified as 'Extremely Urgent', the letter urges all provincial governors and district officials in the country to be determined to address legal status and nationality issues in honour of the $70^{\text {th }}$ anniversary of his reign, prompting one to wonder what would come after the commemoration. ${ }^{3}$ The letter summarises the principles of obtaining Thai citizenship and outlines specific instructions and warnings for operational bureaucrats. ${ }^{4}$ Attached to the letter is an eight-page document containing flow charts with a detailed break-down of the required documentary evidence and the appropriate decision-making for a multitude of legal scenarios. ${ }^{5}$ In addition to reminding local officials to follow strictly the rules and protocols, it also urges them to be careful not to create any opportunities for any exploitations or corruption regarding civil registration and citizenship granting. The letter also encourages the flow charts be printed off and posted in local district offices so that they are visible to the public. ${ }^{6}$ The letter and the methodological charts indicate a serious attempt to standardise bureaucratic practices. They also suggest that once a case undergoes proper 'diagnosis', ${ }^{7}$ a legal solution will emerge and will be smoothly executed.

As a country with a large stateless population, Thailand is a key target country for the United Nations High Commissioner for Refugees ('UNHCR')'s global campaign on statelessness eradication by 2024 (also known as \#IBELONG). ${ }^{8}$ While it is widely acknowledged that statelessness is complex and multi-faceted, with 'no singular appropriate way to respond', 9 statelessness in Thailand is primarily cast by the state and some activists as an individual legal status issue, which can be resolved by standardised evidentiary procedures. During my fieldwork, I encountered statelessness being described by some activists and

2 Letter from Ministry of Interior (Thailand) to the Governor of each province, 12 May 2016 $[\operatorname{tr} \quad$ author] ('2016 Letter') $<$ https://www.bora.dopa.go.th/nationclinic/images/document/Citizenshipdiagnostics.pdf>. I have observed that this usage in the official communication could be considered as the success of the non-governmental organisation networks in their campaign, but this is not the objective of my research.

3 ibid 1. I conducted my fieldwork intermittently from September 2015 - January 2018, totalling 12 months. My fieldwork started before, and lasted after, King Bhumibol's death in October 2016. This letter was issued before his death.

42016 Letter (n 2). These warnings include 'beware of new illegal immigrants or labour migrants who claim to be members of highland communities': at 2 [4.4].

5 ibid 4, citing Permanent Secretary of the Interior, Guidance on Diagnosing Nationality and Resolving Legal Status Issues (Guidelines, 12 May 2016) $<$ https://www.bora.dopa.go.th/nationclinic/images/document/Citizenshipdiagnostics.pdf>.

$6 \quad 2016$ Letter (n 2) 3.

7 ibid 4.

8 '\#IBelong Campaign to End Statelessness', United Nations High Commissioner for Refugees (Web Page) <https://www.unhcr.org/en-au/ibelong-campaign-to-end-statelessness.html>.

9 Tendayi Bloom, Katherine Tonkiss and Phillip Cole (eds), Understanding Statelessness (Routledge 2017) 2; see also Benjamin Lawrance and Jacqueline Stevens (eds) Citizenship in Question: Evidentiary Birthright and Statelessness (Duke University Press 2017); Jacqueline Bhabha (ed) Children Without a State (The MIT Press 2011). 
officials as a disease, an anomaly. ${ }^{10}$ Using the language of pathology, they insist that 'diagnosing statelessness' be done through objective assessment of the types of state-issued documents (or lack thereof) possessed by a stateless person. In other words, statelessness is framed first and foremost as an issue of legibility to the state, with an assumption that once a stateless person is 'properly seen', due recognition will follow. This approach seems to produce a promising outcome since 2011, over 23,000 stateless persons have been granted citizenship, earning Thailand praise from UNHCR for its 'progressive nationality strategy'.11 Thailand's dramatic rate of statelessness reduction seems to confirm UNHCR's claim that 'with adequate leadership and effective implementation, statelessness can be ended'. ${ }^{12}$ What, then, is the problem of framing statelessness as an individual's documentary issue? What are the implications of portraying 'statelessness diagnosis' as a fair and rational process?

In this article, I explore these questions using three ethnographic accounts in which stateless persons in northern Thailand face difficulties getting the Thai state to recognise the validity of the documents in their possession, which were issued by the state itself. In examining the complex entanglements of bureaucracy, documentation and statelessness, the article joins a growing body of literature that examines the limits of the evidentiary approach and the burden of proving citizenship as experienced by many stateless persons around the world. ${ }^{13}$ It builds on and extends the works of scholars on the plight of citizenship among highlanders in northern Thailand, ${ }^{14}$ especially Amanda Flaim's illuminating ethnography and argument on how citizenship conferral ultimately requires the conferral of belief by officials. ${ }^{15}$ I use the anthropological framework of 'state illegibility' 16 to encapsulate systemic violence and burden placed on stateless persons by the state's opaqueness and inscrutable, contradictory and unpredictable bureaucratic practices. State illegibility, according to Veena Das, makes the legal and the illegal in the everyday life become hard to distinguish for the affected

10 Fieldwork in Janepicha Cheva-Isarakul, 'Navigating the Illegible State: Everyday Experiences of Statelessness among Shan Youth in Northern Thailand' (PhD Thesis, Victoria University of Wellington) (Forthcoming).

11 'Thailand', United Nations High Commissioner for Refugees (Web Page) $<$ https://www.unhcr.org/ibelong/imvisible-thailand/>.

12 'Global Action Plan to End Statelessness: 2014-2024', United Nations High Commissioner for Refugees (Web Page) <https://www.unhcr.org/ibelong/global-action-plan-2014-2024/>.

13 See Lawrance and Stevens (n 9).

14 A Right to Belong (Ophidian Films Ltd 2002); Mika Toyota 'Subjects of the Nation Without Citizenship: The Case of "Hill Tribes" in Thailand' in Will Kymlicka and Baogang He (eds) Multiculturalism in Asia (Oxford University Press 2005); Chutima Morlaeku, 'Challenges and Opportunities: Searching for Answers to the Lingering Questions of Legal Status in Thailand' (Internal Report, United Nations United Nations Educational, Scientific and Cultural Organization 2010); Mukdawan Sakboon, 'Citizenship and Education as the Basis for National Integration of Ethnic Minorities in North Thailand' (PhD Dissertation, Macquarie University 2009); Amanda Flaim, 'Problems of Evidence, Evidence of Problems: Expanding Citizenship and Reproducing Statelessness among Highlanders in Northern Thailand' in Benjamin Lawrance and Jacqueline Stevens (eds), Citizenship in Question: Evidentiary Birthright and Statelessness (Duke University Press 2017).

15 Amanda Flaim argues that 'protracted statelessness persists in Thailand, paradoxically as a result of the bureaucratic and evidentiary procedures and the citizenship application process enacted to address it': Flaim (n 14) 148.

16 Veena Das, 'The Signature of the State: The Paradox of Illegibility' in Veena Das and Deborah Poole (eds), Anthropology in the Margins of the State (School of American Research Press 2004); Stephen Campbell, 'State Illegibility in the Containment of Labour Unrest on the Thai-Myanmar Border’ (2017) 37(3) Critique of Anthropology 317. 
group that fails to 'read' the state's rules and understand what is happening. ${ }^{17}$ Stephen Campbell further argues that state illegibility produces 'uncertainty and insecurity for those at whom the practices are directed. Rather than aberrant, this illegibility is centrally constitutive of the state itself'.18 Through three ethnographic accounts in Thailand, I interrogate various forms of state illegibility in attempt to understand why a meticulous recordkeeping practiced by the stateless persons in these vignettes has failed to improve their legal status. Is state illegibility simply synonymous with, or masked as, weak bureaucracy? Do stateless persons fail to 'read' the state as suggested by Das and Campbell?

I argue that the state illegibility framework not only affirms Flaim's argument on the myth of fair bureaucracy and an even production of evidence by the state, but reveals the process by which the bureaucratic burden of statelessness is placed upon the stateless. By portraying statelessness as a personal legal status issue to be resolved using a fair and rational evidentiary procedure, the Thai state downplays its past and present illegible documentary practices and marginalisation against certain minority groups and in turn shifts responsibility to stateless individuals. In other words, the assertion of standardised evidentiary procedures frames a root cause of statelessness as an individual's neglect and inability to provide 'proper' documents without recognising the state's own unstable documentary practices, and is in itself an act of violence. By not recognising state illegibility, statelessness risks being reduced to an individualised legal status issue, rather than being recognised as a symptom of systemic discrimination.

In the following Parts, I will first explain my methodology and establish my positionality before providing the historical and social context of statelessness in Thailand. Then I will use three ethnographic accounts to illustrate forms of state illegibility and explore the implications of failing to recognise them.

\section{Notes on Methodology AND Positionality}

As a research method, 'ethnography is a mode of knowing that privileges experience', 19 and thus provides rich and important insights into social relations and the lived experience of the researched. The ethnographic accounts presented in this paper were collected in 2016-18 as part of my larger $\mathrm{PhD}$ research project that examines everyday experience of statelessness among ethnic Shan youth in northern Thailand. ${ }^{20}$ While the key participants of my $\mathrm{PhD}$ research are stateless Shan youth living and attending school in urban areas of Chiang Mai, I also had opportunities to interact with other stateless communities during my 13-month fieldwork such as the ones in this article. The data for this piece was collected

17 Das (n 16) 231.

18 Campbell (n 16) 318-19.

19 Veena Das and Deborah Poole (eds) Anthropology at the Margins of the State (School of American Research Press 2004) 4.

20 The fieldwork for my PhD research was conducted intermittently during 2015-18, totalling 13 months. I used a range of ethnographic research methods such as participant observation, focus-group interviews, semi-structured interviews and a photo-elicitation method. In addition to conducting participant observation in venues frequented by my youth participants, I have had a parallel engagement with policy-level discussions on addressing statelessness. I also conducted interviews with several bureaucrats at both operative and management levels, as well as textual analysis of relevant policies and the Thai state's official communications materials regarding statelessness. 
using ethnographic methods namely participant observation and informal interview.

The timing of my $\mathrm{PhD}$ project coincides with UNHCR's global campaign to eradicate statelessness by 2024 that was launched in 2014. ${ }^{21}$ As a westerneducated middle-class Thai citizen with previous work experience within the civil society sector, I have benefitted from my existing networks and familiarity with the international and local NGOs, bureaucrats and policymakers. Several times during my fieldwork, I was unexpectedly and informally invited by various NGO leaders to attend several high-level intergovernmental meetings and other exclusive events. One of such events was a fieldtrip with the National Human Rights Commission ('NHRC'), which produced two ethnographic cases presented in this article. My social and cultural capital have allowed me to access sites and information that may not have otherwise been made available to other researchers.

The long-term nature of ethnographic research has allowed me to earn the trust of my core youth participants and their families. Over the years, I spent time with them in various settings including households, workplaces, festivals, schools and sometimes district offices. In a highly stratified society such as Thailand, aspects of my identity particularly my class, gender (female) and western upbringing contribute to the dynamics of my relationship with my participants. At the same time, having spent nearly half of my life outside of Thailand, I am positioned as a halfie researcher, "whose cultural identity is mixed by virtue of migration, overseas education and parentage'. ${ }^{22}$ This identity, which I discuss in more detail in my forthcoming thesis, ${ }^{23}$ makes me stand out to my youth participants, who perceive me as someone who does not represent or embody Thai-ness in the same way as other Thai adults they know (especially their teachers and state authorities). In other words, my halfie identity has permitted me to navigate the world of Thai social hierarchy but also be positioned away from it.

All the names of stateless persons in this article are pseudonyms. I also have changed the names of the districts to further protect their confidentiality. However, in the first two ethnographic accounts, the visits were official visits alongside the NHRC and so I do not suppress their details.

\section{BACKGROUND ON STATELESSNESS IN THAILAND}

Thailand has one of the largest stateless populations in the world, ${ }^{24}$ despite its relatively open nationality laws which recognise both jus soli and jus sanguinis as principles of granting citizenship. ${ }^{25}$ However, closer reading reveals jus soli only applies under certain circumstances: a non-Thai person born to illegal aliens under a selected time period specified by the laws can apply for citizenship, provided that the application is accompanied by required documentary proof. ${ }^{26}$ Principles of granting citizenship therefore are not simply the matter of blood (lineage) and soil (by birth) but also, perhaps more importantly, paper (proof of birth within a

21 '\#IBelong Campaign to End Statelessness', United Nations High Commissioner for Refugees (Web Page) <https://www.unhcr.org/en-au/ibelong-campaign-to-end-statelessness.html $>$.

22 Lila Abu-Lughod 'Writing against Culture' in Richard Fox (ed), Recapturing Anthropology: Working in the Present (School of American Research Press 1991) 137.

23 See Cheva-Isarakul (n 10).

24 Institute on Statelessness and Inclusion, Statelessness in Numbers: 2018 (Report, June 2018) $<$ https://www.institutesi.org/ISI_statistics_analysis_2018.pdf $>$.

25 Nationality Act B E 2508 (Thailand) 21 July 1965, ch 1 ss 6, 7 ('Nationality Act').

26 ibid 7 bis. 
specific window of time). Getting a combination of these elements right is a complicated affair. To add further complexity, a child's legal status is determined by that of the parents, making statelessness an inherited transgenerational experience. ${ }^{27}$

With discrimination against minorities being one of the key causes of statelessness globally, ${ }^{28}$ it is not a coincidence that most stateless persons are considered 'ethnic minorities' who reside in the northern region. ${ }^{29}$ They are the members of the nine ethnic groups officially classified as 'hill tribes', 30 other highlanders not classified as 'hill tribes' and children of migrants, who were born in Thailand and do not have ties to their parents' country of origin. ${ }^{31}$ As argued by Flaim, the generally acknowledged causes of statelessness in the Global South such as state succession and state failure do not explain the phenomenal number of in situ stateless persons in Thailand. ${ }^{32}$ For Flaim, systemic discrimination and exclusion against ethnic minorities, ${ }^{33}$ along with bureaucratic failure, erratic and incomplete registration and legal loopholes account only in part for widespread statelessness in northern Thailand. ${ }^{34}$ Arguing that 'protracted statelessness... persists, paradoxically, as a result of the bureaucratic practices and procedures that have been enacted to address it', ${ }^{35}$ Flaim shines a light on what she calls 'the fictions of the rule'. ${ }^{36}$ Flaim's work emphasises the importance of historicisation and contextualisation of nationality laws, policies and social practices in order to understand the complex dynamic of how the laws and policies are understood and interpreted by authorities.

To understand why some groups of people are not considered 'authentic Thai', to use the late King's words, we must briefly visit the social construction of Thai national identity. The twentieth-century nation-building project of the modern Thai state resulted in the imagined identity of Thai nationality as largely synonymous to 'the Thai race/ethnicity'; cultural differences and ethnic heterogeneity were considered a threat to national stability. ${ }^{37}$ Well-documented

27 See ibid ch 1.

28 Fernand de Varennes, Report of the Special Rapporteur on Minority Issues, UN Doc A/HRC/40/64 (9 January 2019) 12 [85].

29 There are other stateless groups found in other parts of the country such as the Moken, a maritime mobile population in the Andaman sea, but they constitute a much smaller group as compared to the North.

30 However, with negative connotations attached to this term, I will use the term 'highland communities' and 'highlanders' instead except when quoting the laws.

31 Among the migrants themselves, those who arrived before the formalisation of labour migration regimes (ie before 2009) are classified as 'persons without legal status', rather than 'temporary migrants', and are allowed to stay for a duration of ten years, subject to renewal. I later elaborate more in this article under Part IV 'Legibility Tools and Technology of Governing'.

32 Flaim (n 14) 148.

33 ibid. Here, Flaim cites a number of sources. See Thongchai Winichakul and Siam Mapped, $A$ History of the Geo-Body of a Nation (University of Hawaii Press 1994); Thongchai Winichakul, 'The Others Within: Travel and Ethno-Spatial Differentiation of Siamese Subjects: 1885-1910' in Andrew Turton (ed), Civility and Savagery: Social Identity in Thai States (Curzon 2000); Thongchai Winichakul, "The Quest for "Siwilai": A Geographical Discourse of Civilizational Thinking in the Late Nineteenth and Early Twentieth-Century Siam' (2000) 59(3) Journal of Asian Studies 528; Pinkaew Laungaramsri, 'Ethnicity and the Politics of Ethnic Classification in Thailand' in Colin Mackerras (ed), Ethnicity in Asia (Routledge Curzon 2003). See also Toyota (n 14); Morlaeku (n 14).

34 Flaim (n 14) 148.

35 ibid 148.

36 ibid.

37 Laungaramsri, 'Ethnicity' (n 33) 160. 
discrimination against the non-Thai 'Other', particularly the Chinese reflects the aggressive assimilation policies implemented by the Thai state during the midtwentieth century. 38 This model of racialised citizenship has successfully turned ethnic heterogeneous society into a homogenous modern nation-state, while curating 'distinctive characteristics separating Thais and the non-Thai'. ${ }^{39}$ While the non-Thai others such as the Chinese also suffered early exclusion from Thai citizenship, they eventually became assimilated through an aggressive assimilation policy. ${ }^{40}$ On the other hand, the highlanders living in the periphery had long been constructed by the Bangkok elites as strange and uncivilisable, thus an anti-thesis to civilised 'Thainess'. ${ }^{41}$ Even the official label 'chao khao' (ชาวเขา) is indicative; the translation can be double-entendre as 'peoples of the hills' and 'the Other' (khao is also a third-person pronoun — 'other'). ${ }^{42}$ To the Thai state, highlanders are therefore 'the Other Within'. ${ }^{43}$ Exclusion from the Thai identity meant highlanders were not included in early state cadastral surveys and were not registered until 1960s. ${ }^{44}$ During the Cold War, negative narratives surrounding highlanders linked them with illicit activities such as deforestation, communism and drug trafficking. ${ }^{45}$ These derogatory stereotypes were used to both justify their exclusion from citizenship and make them objects of 'development' ${ }^{46}$

In the past, not being seen and counted by the state may have had little impact on the everyday life of the highlanders who lived at the margins of the state such as the highlanders in northern Thailand but by the 1990s, not being documented and not having Thai citizenship became a serious problem. ${ }^{47}$ Diminished livelihoods in the highlands coupled with restrictions placed on the movement and occupations of non-citizens turned statelessness into a critical issue among the highlanders. ${ }^{48}$ Intimidation by representatives of the state is common. ${ }^{49}$ As is discrimination, such as not having access to education or not being granted a certificate of completion for those who were able to attend school. ${ }^{50}$ Mobilisation during 1999 and 2000 by pan-highland movements led to mass registration of highlanders, many of whom successfully obtained Thai citizenship. ${ }^{51}$ However, as

38 See generally William G Skinner, Chinese Society in Thailand: An Analytical History (Cornell University Press 1957); Laungaramsri, 'Ethnicity' (n 33).

39 Laungaramsri, 'Ethnicity' (n 33) 160; David Streckfuss, 'The Mixed Colonial Legacy in Siam: Origins of Thai Racialist Thought, 1890-1910' in Laurie Sears (ed), Autonomous Histories, Particular Truths: Essays in the Honor of John $R W$ Smail (Centre for Southeast Asian Studies) 123, 123-153. See also David Streckfuss, "An "Ethnic" Reading of "Thai" History in the Twilight of the Century-Old Official "Thai" National Model' (2012) 20(3) South East Asia Research 305.

40 Laungaramsri, 'Ethnicity' (n 33) 161; Duncan McCargo, 'Informal Citizens: Graduated Citizenship in Southern Thailand' (2011) 34(5) Ethnic and Racial Studies 833, 837.

41 Winichakul, 'The Others Within' (n 33) 45-48.

42 Laungaramsri, 'Ethnicity' (n 33) 163.

43 Winichakul, 'The Others Within' (n 33).

44 Flaim (n 14) 149-50.

45 Laungaramsri, 'Ethnicity' (n 33) 165-67.

46 Flaim (n 14) 150.

47 A Right To Belong (n 14).

48 Flaim (n 14) 150-51.

49 Cheva-Isarakul (n 10).

50 ibid.

51 Flaim (n 14) 150-51, citing Kathryn McKinnon '(Im)Mobilization and Hegemony: "Hill Tribe" Subjects and the "Thai" State' (2005) 6(1) Social and Cultural Geography 31; Morlaeku (n 14). 
shown in Flaim's work, registration was still uneven and legal status among members of the same family may differ. ${ }^{52}$

While prejudice against highlanders, which has led to their statelessness has been well documented and examined, much less is theorised or studied in relation to statelessness among the children of labour migrants, notably the ethnic Shan, from the Shan state of Myanmar, who constitute a large group in Chiang Mai. ${ }^{53}$ Prior to UNHCR's \#IBELONG campaign, it was more common to refer to the Thai-born children of Shan migrants as 'second generation immigrants'; their risk of statelessness was not necessarily widely recognised. ${ }^{54}$ Statelessness, among what Jacqueline Bhabha calls 'Arendt's Children', has so far received comparatively little attention, partly due to their contentious status. Some NGOs and officials I met during my PhD fieldwork expressed that they are 'unauthentic stateless' - especially when some parents hold a labour migrant passport issued by a country of origin. ${ }^{55}$ It is not within the scope of this article to debate their legal predicaments, but the daily experience of the children who are the participants in my $\mathrm{PhD}$ research suggests that they possess 'significant and stable ties' with Thailand. ${ }^{56}$ For my research, and in this article, I regard them as de facto stateless.

52 Flaim (n 14).

53 Due to its proximity to the Shan state of Myanmar and the 'porous' nature of borders, there had long been movements and settlement of ethnic Shan people in Chiang Mai and other northern provinces. Early migrants who entered Thailand before labour regularisation started in 1990s were not classified as migrants but as 'highlanders' (but not hill tribes). For more information on the Shan diaspora in Northern Thailand, see Amporn Jirattikorn, 'Brokers of Nostalgia: Shan Migrant Public Spheres in Chiang Mai, Thailand', in Caroline Plüss and Chan Kwok-bun (eds), Living Intersections: Transnational Migrant Identifications in Asia (Springer 2012).

54 Bupa Anasuchartkul, รูปแบบและการจัดการศึกษาแก่สำหรับทายาทรุ่นที่สองของผู้ย้ายถิ่นจาก ประเทศพม่า [Education Models for the Second Generation Migrants from Myanmar] (Report, Thailand Research Fund 2011) [tr author]; Kamonwan Petchot, 'The Right to Education for Migrant Children in Thailand: Liminal Legality and the Educational Experience of Migrant Children in Samut Sakhon' in Thanh-Dam Truong et al (eds), Migration, Gender and Social Justice: Perspectives on Human Insecurity (Springer, 2014); Kwancheewan Buadaeng, การปรับตัวทางสังคมและวัฒนธรรมของทายาทรุ่นที่ 2 ของผู้ย้ายถิ่นจากประเทศพม่า [Social and Cultural Regormation of Second Generation Migrants from Myanmar] (Report, Thailand Research Fund, 2011) [tr author]; Nongyao Nawarat 'Thailand Education Policy for Migrant Children from Burma' (2012) 47 Procedia - Social and Behavioural Sciences 956; Nongyao Nawarat, 'Negotiating Curricula for Burma Migrant Schooling in Thailand' (2014) 143 Procedia - Social and Behavioural Sciences 872 .

55 Jacqueline Bhabha, 'Arendt's Children: Do Today's Migrant Children Have a Right to Have Rights?' (2009) 31(2) Human Rights Quarterly 410. Bhabha explains the defining characteristics of a group she calls 'Arendt's children' as that

they are minors; they are, or they risk being separated from their parents or customary guardians; and they do not in fact (regardless of whether they do in law) have a country to call their own because they are either noncitizens of children of noncitizens. Within this term includes citizen or migrant children living in so-called 'mixed status' or 'undocumented families'; unregistered or stateless children living in their country of birth with their immigrant parents.

At 413. Kritaya Archavanitkul, 'Towards Managing Stateless People in Thailand's Context' (2014) 118 Senri Ethnological Reports 185; Phunthip Kanchanachittra Saisoonthorn, 'Development of Concepts of Nationality and Efforts to Reduce Statelessness in Thailand' (2006) 25(3) Refugee Survey Quarterly 40, 52.

56 Cheva-Isarakul (n 10). 


\section{LEgIBILITY TOOLS AND TECHNOLOGY OF GOVERNING}

James Scott argues that legibility is a central problem in statecraft; a modern state seeks to 'see' and 'know' its population using various legibility tools in order to assert control; population registration and identification are among the key tools. ${ }^{57}$ From the first identity card issued to residents of Bangkok and Thonburi in 1943 until today, the Thai state's legibility practices have evolved to be more tightened, integrated and sophisticated. ${ }^{58}$ Since 1983, the Thai state has employed the 13digit personal identification number to document the subjects in its territory. ${ }^{59}$ Each digit contains specific information about the person such as the province at which they were registered and, to an extent, reveals their relationship to the state (Thai citizen or non-citizen). ${ }^{60}$ In principle, the same personal identification number appears across all official documents, suggesting a coherent system that tracks and traces a person's documentary records. ${ }^{61}$ While the database connectivity makes the state appear omnipresent, 'knowing' and 'seeing' all its populations, there are still identity discrepancies and loopholes in the bureaucracy as shall be demonstrated by one of the ethnographic accounts later.

In the case of Thailand, the national identification system - in the forms of an identification card and a 13-digit number — is among key practices to make society legible. It has been historically set up not for universal allocation of rights, but for ethnological classification, surveillance and differentiation . ${ }^{62}$ The personal identification number and the identification card not only demarcate scopes of physical and social mobility but also a pathway toward citizenship. ${ }^{63}$ The first digit, in particular, suggests how a person is categorised by the state. A Thai citizen born after 1984, for example, is assigned number one as the first digit in their personal identification number, while those classified as 'hill tribes' and '[o]ther highlanders who are not hill tribes' are usually assigned number six, suggesting their status as long-term alien residents. ${ }^{64}$ An offspring of a number six card holder is usually issued a number seven card. The number six and seven card holders may be able to apply for Thai citizenship through s 7 bis (2) given that they satisfy other

57 James C Scott, Seeing Like a State: How Certain Schemes to Improve the Human Condition Have Failed (Yale University Press 1998) 2.

58 Pinkaew Laungaramsri, 'Contested Citizenship: Cards, Colors and the Culture of Identification' in John A Marston (ed), Ethnicity, Borders, and the Grassroots Interface with the State: Studies on Southeast Asia (Silkworm Books 2014) 143. Laungaramsri has also published a book in Thai in 2018 that explores in depth the history and bureaucratic practices of the Thai state with regards to population registration, identification card and other identity documentation: Pinkaew Laungaramsri, Identity Documents: Genealogy of Population Control in Thailand (Research Administration Centre Chiang Mai University 2018) in Thai: ปิ่นแก้ว เหลืองอร่ามศรี อัตลักษณ์เอกสาร: วงศาวิทยาการควบคุมประชากรของรัฐไทย (ศูนย์บริหารงานวิจัย มหาวิทยาลัยเชียงใหม่ 2561 ).

59 Archavanitkul (n 55) 186.

60 ibid. See also ระเบียบสำนักทะเบียนกลาง วาดวยการจัดทำทะเบียนราษฎร [Regulations of the National Registration Office on Civil Registration] (Thailand) Statute No 151-52, 125 Royal Thai Government Gazette 46, 26 November 2008, art 152(2).

61 Passports and driver licenses have their own series numbers but still display the 13 digit identification numbers.

62 Laungaramsri, 'Contested Citizenship' (n 58) 148; Toyota (n 14) 111, 120.

63 Stateless highlanders and other persons without legal status are physically confined to a province under which they are registered. Until 2016, they were only elgibile to hold one of 27 specified occupations. See 'Thailand' United Nations High Commissioner for Refugees (Web Page) <https://www.unhcr.org/ibelong/imvisible-thailand/>. See also Grisada Boonrach, Statelessness Situation and Thailand's Solutions, tr Bongkot Napaumporn (Report, Ministry of Interior 2017) 9 n 23 ('Statelessness Situation and Thailand's Solutions').

64 Cheva-Isarakul (n 10). 
documentary requirements including proof of birth and residency. ${ }^{65}$ However, in practice the regime of identification cards is far from stable and truly representative of a person's identity, especially along the border areas where the issuance and revocation of cards have become common state practices. ${ }^{66}$

Mass labour migration from the neighbouring countries to Thailand during its economic boom in 1990s further complicated the country's situation of statelessness and the regime of identification. A largely migrant-export country until the early 1990s, Thailand initially struggled to regularise the massive influx of labour migrants from the Greater Mekong Sub-region. ${ }^{67}$ Its early labour migration policies have been described as a 'series of practical responses to unfolding events and changes in labor needs'. ${ }^{68}$ Similar to the experience of the highlanders, registration of migrants and children of migrants was erratic and uneven. ${ }^{69}$ Many of these children who were born in Thailand or brought to the country as a child are at risk of statelessness due to exclusion from nationality laws and lack of documentary proof from both Thailand and the country of origin. ${ }^{70}$ Between 2005-09, the Thai state implemented the 'Strategy on Managing People with Personal Legal Status Problems and Rights' (ยุทธศาสตร์การจัดการปัญหาสถานะและสิทธิบุคคล) by conducting massive countrywide surveys and issuing a 'person-without-legal status' identification card (บุคคลไม่มีสถานะทางทะเบียน), also known as a zero card or 10-year card as it permits a non-Thai person to temporary reside in Thailand for 10 years. ${ }^{71}$ This zero card is a common identity document among children of migrants in northern Thailand who were surveyed during this period. ${ }^{72}$ With the arbitrary and inconsistent nature of registration, it is also not uncommon for a person who should have been entitled for a number six card to end up with the zero card.

Given the hierarchy within the regime of identification cards, they are therefore not only a state instrument of control but, as argued by Pinkaew Laungaramsri, 'survival resources to be assessed, classified and circulated according to a hierarchy of values', leading to various strategies to upgrade one's status to emerge, such as selling the identification cards of deceased highlanders to the new immigrants and adding the names of new immigrants into the highlanders' households to get a highlander card. ${ }^{73}$

65 Nationality Act (n 25) s 7 bis (2).

66 Laungaramsri, 'Contested Citizenship' (n 58) 144.

67 Ana Revenga et al, Labor Migration in the Greater Mekong Sub-Region (Synthesis Report Phase 1, November 2006) 30; Supang Chantavanich, 'Thailand's Responses to Transnational Migration During Economic Growth and Economic Downturn' (1999) 14(1) Sojourn: Journal of Social Issues in Southeast Asia 159, 161; Pracha Vasuprasat, Agenda for Labour Migration Policy in Thailand: Towards Long-Term Competitiveness (Report, International Labour Organization 2010) iii.

68 Revenga (n 67) 10.

69 Premjai Vungsiriphisal, Siwaporn Auasalung and Supang Chantavanich, Migrant Children in Difficult Circumstances in Thailand (Report, The Asian Research Center for Migration, 17 July 2010).

70 Archavanitkul (n 55) 141.

71 ibid 193.

72 ibid.

73 Laungaramsri, 'Contested Citizenship' (n 58) 159-160. 


\section{Expanding Rights of Stateless Persons and Continual Grey Areas}

Stateless persons in Thailand are not a homogenous group; their incorporation into Thai society depends largely on the timing of their birth, their ethnicity as classified by the Thai state and the documents they possess. In addition to the complex regime of governing statelessness, what makes Thailand a unique case study for modern-day statelessness is that stateless persons are both marginalised from and included in the formal systems. Since 2005, the rights of non-citizens have been progressively expanded. The 'Education for All' Cabinet resolution passed in 2005 grants access to education for all children in the country regardless of their legal status. ${ }^{74}$ The amendments made to the Civil Registration Act 2008 also allow universal birth registration for all children born in the country regardless of their legal status. ${ }^{75}$ As compared to the generations before them, stateless children and youth in northern Thailand born after the year 2000 are likely to be more integrated or included into the state system. ${ }^{76}$ This partial social and legal incorporation means some stateless persons, in the words of my participants, 'grew up normal' 77 and were not truly aware of the implications of not having citizenship. It is usually not until they reach teenage years (from around 13 years old) that they become aware of their 'abnormal' legal condition and the barriers imposed on their social and physical mobility.

In the last few years, the Thai state has been passing significant amendments to the citizenship laws that theoretically open a much wider door for obtaining Thai citizenship. Confirming the message in the official letter at the beginning of this article, the late King Bhumibol's platinum jubilee in 2017 was cited to me by activists in the field as a main motivator for unprecedented urgency to solve statelessness, especially among children. Statelessness even gained a temporary limelight when the former Permanent Secretary of the Ministry of Interior published an article in mainstream media: 'Statelessness Situation and Thailand's Solutions' ${ }^{78}$ The Cabinet resolution passed on 7 December 2016 also states that stateless children and youth born to migrants and displaced persons may be considered for Thai citizenship under the conditions that they:

1. possess proof of birth in Thailand;

2. do not possess any other citizenship;

3. have proficiency in Thai (reading and writing);

4. demonstrate loyalty to the monarch;

5. possess a record of good conduct;

6. possess evidence of educational achievement - completion of a Bachelor's degree. ${ }^{79}$

74 Statelessness Situation and Thailand's Solutions (n 63) 9.

75 ibid 5; Civil Registration Act (No 2) (Thailand) B E 2551 (2008).

76 Statelessness Situation and Thailand's Solutions (n 63).

77 'Normal life' here is minimally defined as being documented, having a right to reside and a right to education and healthcare.

78 Grisada Boonrach, 'Statelessness Situation and Thailand's Solutions: Grisada Boonrach (Permanent Secretary, Ministry of Interior)', Matichon (online, 11 July 2017) $<$ https://www.matichon.co.th/article/news_599580>.

79 ibid; Ministry of Foreign Affairs of the Kingdom of Thailand, 'Thailand Announces Additional Measures to Fight Statelessness' (Press Release, 5 January 2017); 'Thailand Opens Citizenship Path for 80,000 Stateless People', Asia Pacific Migration Network (online, 1 January 2017) <http://apmigration.ilo.org/news/thailand-opens-citizenship-path-for-80-000stateless-people>. 
This checklist is difficult to fulfil for many stateless children, whose educational attainment is not likely to reach a tertiary level due to various obstacles. Being Thai under jus soli is therefore not simply a birthright but involves a constant process of proving and becoming. ${ }^{80}$ The criteria also reflect how education is perceived as key to integration and production of 'self-reliant Thai citizen[s]' ${ }^{81}$ The following ethnographic accounts further suggest a complex reality in which documentary requirements are difficult to fulfil, as the state itself could choose to not accept the documents held by stateless persons as valid.

\section{ETHNOGRAPHIC ACCOUNT ONE 82}

In late 2017, I unofficially accompanied the NHRC of Thailand's Sub-Committee on Indigenous and Minority Rights to investigate the complaints put forward by two stateless communities in the outskirt of Chiang Mai, a main city in Northern Thailand. Even though these villages are within a two-hour drive of the city centre and are still officially part of Chiang Mai, they felt rather remote. Within minutes from the turn-off from the main highway, we found ourselves among tall trees on a meandering unpaved road. With a dramatic drop to the left, our van climbed up the shoulders of the hills carefully.

The goal of the visit, as repeated several times during the trip by the investigators, was 'to heal our brothers and sisters' (เยียวยาพี่น้อง), highland communities who had their Thai citizenship stripped from them years ago. The responsibilities of the NHRC include examining

acts of human rights violation or those which do not comply with the country's international human rights obligations and propose remedial measures to individuals or organizations concerned, ${ }^{83}$

and filing 'a lawsuit on behalf of a complainant for the purpose of redressing the problem of human rights violation in general'. ${ }^{84}$ The convener of this SubCommittee at the time of my fieldwork was a former activist well-known for her work with the highland communities and her role as an experienced intermediary between the highlanders and the government. Other team members were seasoned development practitioners, academics and activists who all knew each other well and had worked together as a network to address legal status issues in Thailand. Many of the Sub-Committee members also sit in the multi-lateral working groups to solve statelessness in the north. ${ }^{85}$

80 For some of my participants who have finally received Thai citizenship, this process of 'proving and becoming' persists even after citizenship is conferred but this is not within the scope of this article. This is an area for future research.

81 Sakboon (n 14) examines in depth how national integration policies based on citizenship and education both incorporate and marginalise the highlanders.

82 All quotes not otherwise footnoted in the following Parts are taken as part of my fieldwork. See Cheva-Isarakul (n 10).

83 'Status and Powers of the National Human Rights Commission', National Human Rights Commission of Thailand (Web Page) <http://www.nhrc.or.th/AboutUs/TheCommission/Mandates.aspx>.

84 ibid.

85 However, it is worth noting that the structure of the NHCR remains intertwined with the government. For example, the commissioners and committee members at the time of my fieldwork were appointed by the National Council for Peace and Order, the military junta that has ruled Thailand since 2014. See more on 'History of the Third Batch National Human Rights Commission', National Human Rights Commission of Thailand (Web Page) $<$ http://www.nhrc.or.th/AboutUs/The-Commission/Background-and-History-2.aspx $>$. 
Our first stop was to investigate the impact of mass citizenship revocation on the highland communities in District A. In 2004-05, the Department of Special Investigation ('DSI') claimed that large-scale corruption took place during the process of granting Thai citizenship to these communities in the district. ${ }^{86}$ According to DSI, not all those who were granted Thai citizenship met all the criteria; most applications were incomplete and some evidence was fabricated. ${ }^{87}$ The local government officers involved were condemned as 'the sell-out gang', who betrayed the country and the national security by falsely approving the identities of recent migrants as members of the community. The motive behind unlawful acquisition of Thai citizenship was speculated as to allow transnational criminals from Myanmar to assume Thai identity and traffic drugs and commit crimes. ${ }^{88}$ As a result, the government ordered a mass revocation of the citizenship of more than 5,000 persons and put a 'pause' on all the activities related to their legal status including not issuing their newborn babies with a Thai identification number. Suspension would be lifted once DSI completed a thorough investigation.

This blanket removal of citizenship had been affecting the daily life of these 5,000 villagers for more than a decade. When the villagers followed up, the district officers would say the documents were still with DSI and there was nothing to be done. Such practice was not deemed a violation of human rights, but protection of national security. With the District not wanting to do anything to contradict or disobey the order of a central government agency, an intervention by a neutral entity - such as the NHRC — was needed.

When we finally arrived, we were greeted by the villagers and led to a tribal museum-turned-meeting hall. A long table was set up in the front of the room for the Sub-Committee members, facing rows of chairs occupied by villagers who came from five affected villages in the district. The atmosphere was tense with anticipation. I noticed many villagers holding a folder containing all their official documents, ready to prove their identities to the committee.

After initial greetings, the convener asked for a show of hands of those who could speak Thai, those who attended Thai schools, those who were previously granted Thai citizenship and those who were born in Thailand. Different hands show up at different times. An interpreter was on the side to facilitate communication. The villagers explained how this legal limbo negatively impacted their life. Holding a baby in her arms, a woman next to me shared her worries with me that her baby would not have a future due to lack of citizenship.

86 The Department of Special Investigation ('DSI') was established in 2002 as part of the criminal justice system reform and wider bureaucratic reform during the $2000 \mathrm{~s}$. It sits under the Ministry of Justice of Thailand but operates independently of the Royal Thai Police. DSI is tasked with the investigation of special crimes such as white collar crimes, organised crimes and transnational crimes.

87 'DSI Hurry to Show Performance to Ministry of Interior: More than 5,000 Fake IDs in Maetaeng District', Manager Online (online, 24 October 2006) $<$ https://mgronline.com/crime/detail/9490000131926>.

88 'Aliens "Bribe" Officials', Bangkok Post (online, 25 October 2006) $<$ http://www.pressreader.com/thailand/bangkok-post/20061025/281638185700196> accessed 17 July 2018. 


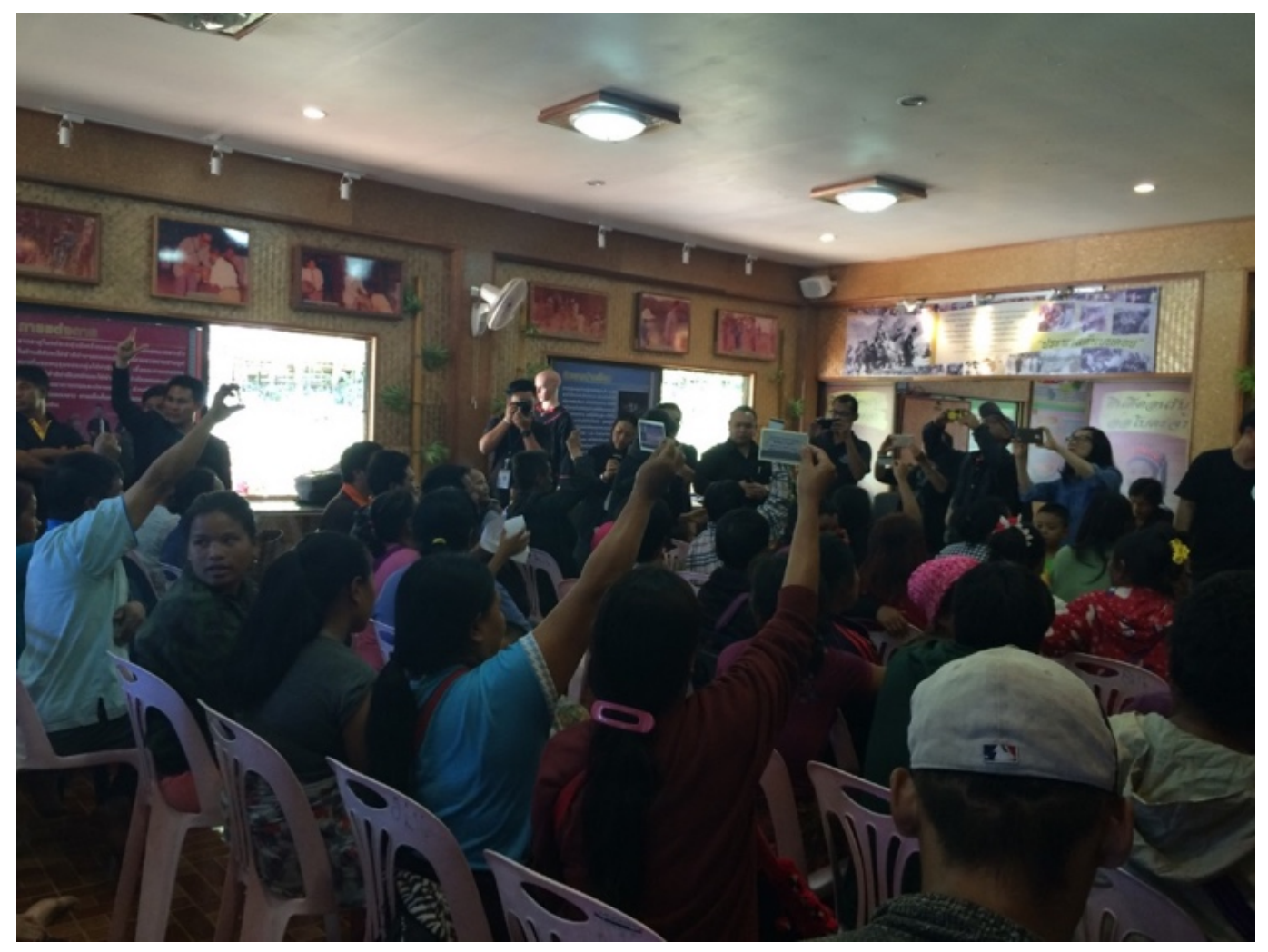

Figure 1: Stateless villagers showing their now-invalid Thai identification cards to the Committee members.

Committee members soon got the villagers to line up in order to investigate the authenticity of their documents. When the convener asked to visit a family home, a man and his wife volunteered. I went along with her while others continued looking through the documents. A short walk up hill from the meeting hall led us to a small tattered house made with bamboo and tin roof. The couple lived alone as their children were now living in Chiang Mai City. They showed us a folder of documents which included a birth certificate and a household registration with mug shots specific to the highlanders. It was clear that they had the documents required by the Thai state to claim Thai citizenship. The couple was particularly worried for their children's future, as this 'pause' in the legal status has been negatively affecting their life for more than a decade. The convener promised to bring justice to the villagers. 


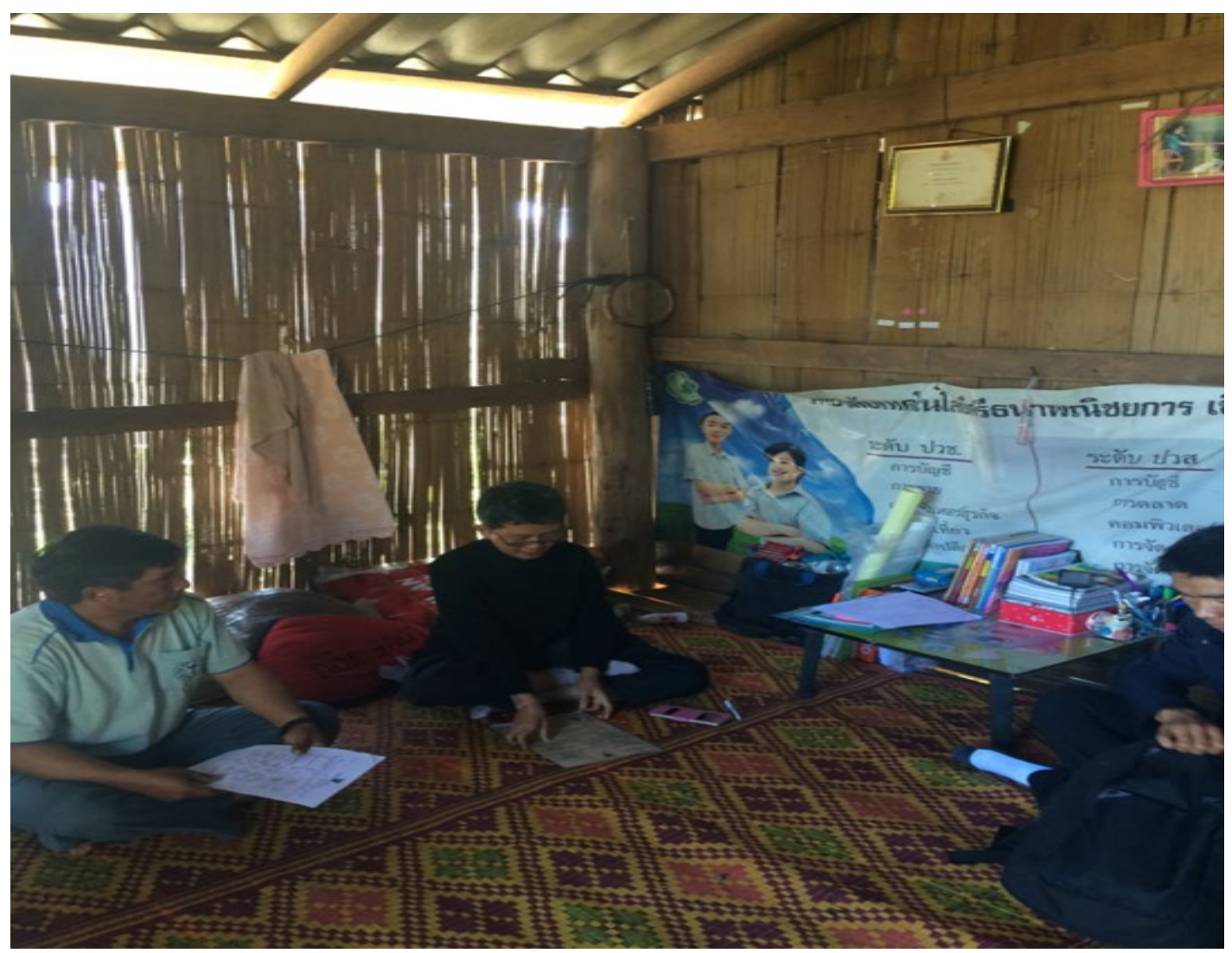

Figure 2: A Convener's visit to a Lahu household.

\section{ETHNOGRAPHIC ACCOUNT TwO}

The second stop on our field visit was a small stateless Hmong community, whose life story complicates existing literature on the relationship between the Hmong and the Thai state and exemplifies state illegibility. During the Cold War, the Thai army and the United States of America Central Intelligence Agency recruited the Hmong communities to fight against the communist insurgents along the ThaiLaos borders through programmes that would ensure both legibility and loyalty to the state such as permanent settlement, military training and citizenship conferral. ${ }^{89}$ These Hmong are officially referred to by the Thai state as 'the Hmong of Wat Thamkrabok'90 (ม้งในที่พักสงฆ์ถ้ำกระบอก), and also sometimes as 'the Hmong who have contributed to Thailand' (ม้งทำคุณประโยชน์). However, more than 40 years have passed and this family still is without the promised citizenship, affecting the lives of subsequent generations. A man in his $50 \mathrm{~s}$, whose father was part of the

89 John McKinnon and Bernard Vienne, Hill Tribes Today: Problems in Change (White LotusOrstom 1989), cited in Flaim (n 14) 154-5; See also William Leary, 'CIA Air Operations in Laos, 1955-1974: Supporting the "Secret War", Central Intelligence Agency (Web Page, 14 April 2007) <https://www.cia.gov/library/center-for-the-study-of-intelligence/csipublications/csi-studies/studies/winter99-00/art7.html>.

90 Wat Thamkrabok is a Thai Buddhist temple where many Hmong took refuge. Ian Baird explores the relationship between the temple and the Hmong people in details in Ian G Baird 'The Monks and the Hmong: The Special Relationship between the Chao Fa and the Tham Krabok Buddhist Temple in Saraburi Province, Thailand' in Vladimir Tikhonov and Torkel Brekke (eds), Buddhism and Violence: Militarism and Buddhism in Modern Asia (Routledge 2013). 
original group of Hmong fighters, explained to us that they moved up north because they had been evicted from Kanjanaburi, where they were placed by the government after the Cold War ended.

Like the first group of villagers, they also had a folder full of various documentary evidences ready to show the committee members. These items included several letters issued by the Thai military circa 1972 confirming their contribution toward 'saving the country'; a well-organised photo album of their home in another province before and during their eviction; pictures of them with one of the most well-known military men in recent Thai history, who later became a Thai Prime Minister in 1996; a type of identification card issued by the Thai Army with a vague message on the back stating 'please facilitate this person', and several more types of identification cards (see figure 3). Despite possessing the letters bearing the Thai government emblem and issued by representatives of the Thai state at various times, the family was told these documents hold no significance. The Sub-Committee members gathered around the table to examine multiple types of identification cards, touching and feeling them. One of the members remarked how unfortunate that none of these cards can be considered valid by the Thai state because they were not issued by the Ministry of Interior. Yet, every single one of them has been kept carefully and safely by the family in hope that one might turn into a valid proof of their 'official' existence. Before our departure, the Hmong man reiterated the urgency of the situation. He told us, 'even animals have a home, but we don't'.

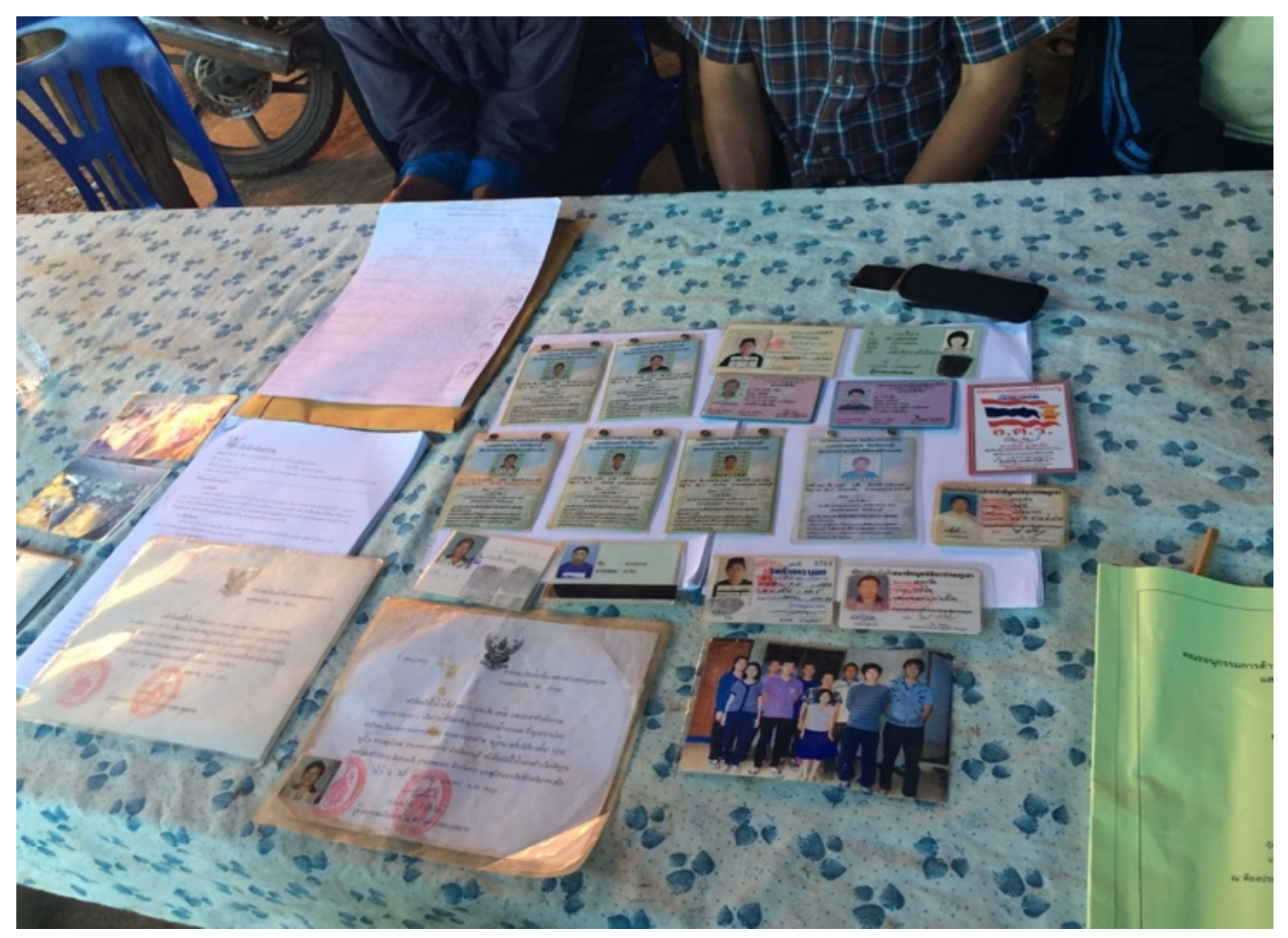

Figure 3: A stateless Hmong's family display of several types of evidence of their identity. 


\section{ETHNOGRAPHIC ACCOUNT THREE: RECONCILING IDENTITIES, JANUARY}

2018

This final account follows a personal quest of my teenage Shan participant to solve the complications surrounding her legal status. I first met $\mathrm{Nida}^{91}$ in 2016 when she was 12 years-old at a 'camp' for construction workers in the outskirt of Chiang Mai. Nida and her parents live in a small three-by-four metre room in a row of structures made of bamboo walls and tin roof. Over the two years of our relationship, I have witnessed Nida's transformation from a carefree child into a serious teenager preoccupied with her legal status. Previously, Nida was registered under two distinct identities in the Thai registration database but she recently found out that at least one of her identities had been withdrawn by the Thai state without her knowledge. Urgency and worry arose, due to the fact that she needed the 13 digit identification number to register for the national examination in order to progress to high school. 'If I cannot resolve my legal situation by then, my future will be hurt', Nida told me.

Nida's parents arrived in Thailand by foot in 1992 from the Shan state of Myanmar, at the cusp of Thailand's first migrant-labour registration. In its first 15 years of labour management, the Thai government often used the amnesty policy and periodic registration to manage irregular migrants. Her parents later were registered and held the one-year work permits issued to aliens when Nida was born at a public hospital in Chiang Mai in 2003. She was registered at birth as Nida B. and her parents were listed as Mong and Mon B. Given her parents' legal status as temporary migrant workers and not highlanders, it is amiss that the identification number issued to Nida's birth certificate started with number seven, implying a pathway for Thai citizenship through s 7 bis (2) of the 2008 Nationality Act. ${ }^{92}$ The top left of her birth certificate issued by District C Office, however, stated 'a person residing in Thailand illegally'. 'Burma' was listed as her nationality. Her address was listed as the Central District, different from her parents' address. ${ }^{93}$ This birth certificate was used to enrol her in school. Despite the conflicting information on her birth certificate, Nida held out hope that she would one day apply for Thai citizenship using this birth certificate.

Under the government-led survey during 2005-09, Nida was registered in District C under another name ('Leena B') and was issued another personalidentification number starting with the number zero. In this registration, her parents' names were also different from the ones on her birth certificate. The nationality was left as blank. ${ }^{94}$ The address listed was that of her aunt who lives in District C. Nida thus has two conflicting identities with two different identification numbers, both granted to her by the Thai authorities from two different districts.

91 A pseudonym.

92 Nationality Act (n 25) s 7 bis (2).

93 The central address is usually used for zero card holders. Thai citizens and permanent resident aliens are registered in a house registration: Thor.Ror 14 (Resident Registration Book, Ministry of Foreign Affairs). Temporary aliens, legal and illegal, are registered under Thor.Ror 13 (Resident Registration Book, Ministry of Foreign Affairs). A house registration is a key document in a citizenship application.

94 Nationality (สัญชาติ) is used here as a synonym for citizenship. 
The crisis surrounding her personal-identity card started in 2015 when Nida, during her visit to a hospital, found out that her zero card was already 'sold' ${ }^{95} \mathrm{Her}$ identity as 'Leena B' had ceased to exist in the official database. Aware that many people like Nida were registered in the district that they did not actually live in, the government verified their addresses by getting them to report to the District Office within a certain period of time. Those who failed to report were deleted from the system.

Initially, Nida did not worry too much, as she still had her birth certificate, which in theory holds more legitimacy than the card. In 2016, Nida went to the District B Office to change the address on her birth certificate from the central address to that of her parents' employer. This change in address is important as residency in a house registration is required in order to apply for Thai citizenship. She was stunned that the identification number on her birth certificate had also been revoked. When inquired upon, the Thai state official said that the identification number linked to her birth certificate was issued by mistake and that a new identification number or a card could not be issued at the moment as the office was commemorating the one year anniversary of the passing of the late King Bhumibol, but that she should come back at another time. From having two identities, now Nida had neither a valid identification card nor a functional legal identity. Her chance of applying for Thai citizenship through s 7 bis (2) no longer existed.

These unexpected changes prompted Nida to take actions to 'save' her legal identity in District C. She had already gone to District C in October 2017 but was told to come back in January 2018 because the District was focusing on organising a commemoration for the anniversary of King Bhumibol's passing. As the new date fell during my short visit to Thailand, Nida and I agreed to meet in District C. Our objective would be to locate Nida's registration form under Leena B (registered under form 89), prove her existence and retrieve her zero number card under this identity.

Despite being an official part of Chiang Mai, the journey to District $\mathrm{C}$ was a four hour ride on the meandering road up the mountains, giving it a sense of remoteness. With Myanmar's border only kilometres away to the north, there were frequent check points and police cars present. No one paid any interest as my car, with a Bangkok license plate, entered the district. The police's attention was more on the vehicles leaving the district to the direction of Chiang Mai.

By the time I finally arrived at the District Office and reunited with Nida and her mother, the place was already crowded with people in the same situation as Nida. Unsurprisingly, the busiest room in the building was the 'Registry Office of District C', its sign written in both Thai and Burmese. The 'citizenship work' section looked particularly busy and dominated by the sounds of the printers, officers shouting names, people coming forward to take a copy of a form certifying identity and registration of persons without legal status. Those on the waiting benches shared a worried expression on their faces, clenching documents in their hands and waiting for their names to be called by the officers. Some had been here for almost two hours already. The reality of waiting starkly contrasted with the prominent signs on the wall promising a smooth workflow and the resolution of each case within 10 minutes.

95 This term is commonly used to refer to a situation where an identification card is revoked and erased from the state's database. An identity can be 'sold' for many reasons such as death and inability to prove residence. 
The notice board displayed the tattered list of people who had been granted Thai citizenship through $\mathrm{s} 7$ bis (2). The columns contained information such as names, addresses, old identification numbers and new identification numbers. According to an official letter issued by the district officer on the notice board, 385 cases of children of migrants have been solved using this law. As a proof, there was a fading photo of happy and smiling children at the swearing-in ceremony organised in honour of King Bhumibol's $70^{\text {th }}$ reigning anniversary. Another announcement stated:

filing for citizenship according to s 7 bis (2) and registration of aliens do not cost anything except administrative fees set by the laws such as fees for issuing certified copies of documents. If anyone claims authority or asks for bribes, please inform the District C Registration Office.

When we approached a stressed-looking officer to ask for a record of Nida's personal information, she insisted that the District had given all the forms to respective village heads. But Nida's village head was nowhere to be found. When Nida's aunt managed to get a hold of him on the phone, it was his turn to insist that the paperwork was with the District office. We were stuck in this back-andforth game, with no one able to tell us where Nida's paper was. When lunchtime came, all the officers locked up the building and went for lunch despite a large number of people waiting to be served.

The afternoon of waiting offered a glimpse of hope when Nida's relative appeared and said he knew the right-hand man of the village head. This man, he said, was much more helpful than his boss. When he appeared, he took us to the back entrance of the building to talk to an officer who had access to some papers to look for Nida's but, at the end, nothing came to fruition.

Nida and her mother decided to take one more day off from their school and work to wait, while I had to return overseas. Through text messages, Nida kept me informed. At one point she wrote, 'they said they would search for my paper in all villages'. It was unclear who 'they' were. Later she wrote 'they said they found the paper but as it turned out, it was not mine. It was of another girl with a similar face'. Apparently, there were many young girls with the 'same face' in the same situation. I put Nida in touch with a Shan youth activist I know, who was making his way to District $C$ to help negotiate and track paperwork for people like her. At the end, they still could not find her paper and the activist said they would have to wait for the District Officer's return to address the issue. The paperwork never turned up.

Although I had previously heard various accounts from my other stateless participants about the difficulties they experienced in dealing with Thai bureaucracy, as a middle-class Thai citizen I had never truly experienced the feelings of limbo, oppression and powerlessness until that day. Only one day spent chasing the paperwork with Nida was enough to overwhelm me with frustration and confusion. Despite the accountability flow-chart or buzz words advertising bureaucratic efficiency all over the District Office, all I witnessed was chaos and the desperation of those who kept waiting without knowing what to do next and how long they had to wait. Yet, the picture of those children getting Thai citizenship on the notice board almost serves as a reminder that citizenship is possible, not something completely out of reach. At the same time, the picture and all those flowcharts also hint that, if you do not get citizenship, it must be because you do not have the right documents and you only have yourself to blame. 


\section{DISCUSSION}

While legibility is considered a 'central problem in statecraft', ${ }^{96}$ it also constitutes a central problem for the stateless, whose hope relies on being 'seen' and 'counted' by the state as a full member. Legibility to the state in the form of documentary evidence therefore sits at the core of the interactions between the state and the stateless. For the highland communities, the Hmong family and Nida, documents are kept and handled with care. This practice not only contradicts sharply with the image of state-evading 'hill peoples' during the pre-modern state era, ${ }^{97}$ but also challenges their contemporary portrayal by mainstream media as ignorant and negligent of documents. Their collective experience affirms existing literature that possession of evidence is not a guarantee for a place in polity and, in turn, reveals to us various forms of state illegibility. ${ }^{98}$ In the name of national security and adherence to the rules, the state could revoke citizenship of groups deemed suspicious, disbelieve the promise and evidence produced by the state itself and disregard documentary mistakes as anomalous errors. Statelessness is therefore a condition deeply entangled with and produced within the complex circular dynamic of needing to be legible to the state but being unable to be due to state illegibility.

\section{A Stereotyping and the Limits of an Individual Identity}

\section{Kelly Staples argues that}

statelessness has often been characterised as a major failing of the state system, but it is a failing that is arguably the result of that very system; in particular, of the way that recognition of individuals has come to be organised. ${ }^{99}$

My ethnographies expand her call for critical engagement with the politics of recognition to illustrate that for many marginalised minority groups, legal inclusion can be fragile even when granted. Despite having achieved full recognition as Thai citizens at one point, the villagers in the first ethnographic account are still not considered 'authentic Thai', to use the late king's words. As a result, their Thai citizenship was collectively revoked due to a negative perception deeply rooted in a long history of discrimination.

Despite this fragility of legal inclusion, stateless persons, in the accounts presented here, still want and seek state recognition in the form of a Thai citizen identification card issued by the Thai state, as such a document not only provides physical and social mobility, but also allows them to be both visible and invisible

$96 \quad \operatorname{Scott}($ n 57) 2.

97 ibid.

98 As argued by Flaim (n 14) 163: 'no evidences, whether documents, data, or even DNA, can ever guarantee a place in the polity'. The other works in the same edited volume by Lawrance and Stevens (n 9) also demonstrate that states produce statelessness in at least two ways: by questioning the citizenship status of their own citizens; and by rendering its own citizens stateless through bureaucratic practices and procedures of concealing and failing to produce evidence that might vindicate an individual's claim to citizenship. As put in the introduction, 'citizens thus are at the mercy of information the agency opposing them is creating, maintaining and hiding from them': Lawrance and Stevens (n 9) 2.

99 Kelly Staples, 'Recognition, Nationality and Statelessness: State-Based Challenges for UNHCR's Plan to End Statelessness' in Tendayi Bloom, Katherine Tonkiss and Phillip Cole (eds), Understanding Statelessness (Routledge 2017) 174; see also Kelly Staples, Retheorising Statelessness: A Background Theory of Membership in World Politics (Edinburgh University Press 2012). 
to the Thai state - visible because a Thai citizen identification card allows them to be officially 'seen' and 'counted' as full members; invisible because once full membership is conferred, in theory, they become one with the masses, holding the same blue coloured identification card as other Thai citizens. A Thai identification card is viewed as a pass to allow them to achieve full social and physical mobility and not have to be under constant threat of being arrested. However, this invisibility is precisely what the Thai state claims is dangerous. In the practice of connecting crimes, especially drug trafficking, to highlanders and migrants, the state views granting or not granting citizenship to highlanders and migrants those deemed the unauthentic Thai - not as a matter of human rights but of national security. Subjected to the state's prejudice, stateless persons in Thailand have been caught in what Malavika Reddy calls a 'double bind', whereby individuals are 'mandated to be identifiable, via their papers, as singular individuals' and at the same time, are stereotyped and perceived as indistinct members of a group. ${ }^{100}$ For the villagers whose citizenship was withdrawn, their identity documents were collectively deemed by DSI as fraud. Instead of reexamining their individual documents to distinguish the genuine from the fabricated, the state agency applied a singular legal action across the board. In Nida's case, for a moment, she was indistinguishable to district officials from another girl 'with the same face' and the same situation. Therefore, despite being required to be individually legible through personal documentation, stateless persons can be seen as all 'the same' to the officials. They become visible only as a group, not as individuals.

Amal De Chickera and Laura Van Waas warn that 'failing to distinguish between the stateless and those who lack documentation, and the failure to distinguish stateless persons who lack documentation, can lead to the wrong solutions'. ${ }^{101}$ However, such distinctions are hard to make in the legal regime, whereby individuals are perceived as indistinct members of a group, and where the state officials are lost in the maze of the many sub-categories of non-citizen 'others', various legal amendments and numerous types of identification cards that the state has created over time. Overwhelmed by the constant policy changes and unable to make the kind of distinction postulated by de Chickera and van Waas, those representing the state often fall back upon the deeply-rooted stereotypical practice. ${ }^{102}$ This knowledge gap within state administrative bodies partly accounts for why many stateless persons in many parts of the world are unable to benefit from theoretically inclusive legal reforms. 103

100 Malavika Reddy, 'Identity Paper/Work/s and the Unmaking of Legal Status in Mae Sot, Thailand', (2015) 2 Asian Journal of Law and Society 251, 263.

101 Laura Van Wass and Amal De Chickera, 'Unpacking Statelessness' in Tendayi Bloom, Katherine Tonkiss and Phillip Cole (eds), Understanding Statelessness (Routledge 2017) 53, 65 (emphasis in original).

102 My informal interview with officers reveal that they often feel unequipped and underresourced to understand the complex Thai citizenship laws.

103 Brad Blitz gives an example from Sri Lanka, where stateless persons could not benefit from a simplified procedure to demonstrate proof of citizenship because state administration bodies were not fully aware of the legal arrangements following the changes in nationality law in 2003: Brad Blitz, 'The State and the Stateless: the Legacy of Hannah Arendt Reconsidered' in Tendayi Bloom, Katherine Tonkiss and Phillip Cole (eds), Understanding Statelessness (Routledge 2017) 71, 77-78. 


\section{B State Illegibility through Documentary Practices}

State illegibility in relation to documentary practices takes various forms. The first form manifests as uneven production of evidence by the state. Nida's two identities, and her later deprivation of both, are case in point. This kind of incident is neither new nor unique to Nida; documentary errors and uneven registration practices by the Thai state are well-known. What is interesting is that despite this knowledge, state agents and those mobilising for rights of stateless persons alike, still insist on viewing legal documents as real and complete. The error in her identity document was normalised as acceptable and consequently was dismissed without much consideration of the possible psychological harms inflicted upon individuals by the delivery of misinformation, or lack of sufficient explanation. Failure to acknowledge unevenness in the state's own bureaucratic practice and insistence on perceiving legal documents as objectively-produced evidence are not only a form of state illegibility but also a form of subtle violence, as it ignores the lived experience of stateless persons, who are left to find a solution for the situation they end up in, without acknowledging how they end up there.

The second form, as mentioned previously, is the fragility of documents. For stateless persons, legal documents are fragile and unstable; they can be presented, accepted and approved but can also be overturned, taken away and removed at any time. A document may be valid today but it may cease to hold any meaning tomorrow, like in Nida's case and the citizenship of the villagers in the first ethnographic account. Alternatively, they could hold no meaning at all despite being issued by the Thai state. In the case of the Hmong family, although the letters and some of the identification cards in their possession were issued by the Thai state, these documents are not considered qualifying evidence for a citizenship application because they were not a birth certificate, a house registration or an identification card containing a 13-digit-number. Even if an official wants to believe their story, they cannot justify granting them citizenship through a normal and standardised channel.

The third form is linked with stereotyping practice. As noted by Flaim, 'no matter how strong the "evidence" to a citizenship claim may be, citizenship conferral ultimately requires the conferral of belief' ${ }^{104}$ Despite the guidelines and flowcharts, the interpretation of evidence also rests on state agents' consideration and willingness to believe. As seen in the first account, a Thai identity card when acquired by a highlander is still met with suspicion as to whether such acquisition is 'truthful'. Assessment of evidence, therefore, is not merely an objective activity, but one that is at risk of stemming from the practice of stereotyping a group. Because stereotyping also depends on an individual's perception of the 'Other', it is unpredictable and is one manifestation of state illegibility.

Finally, while the international legal frameworks state that a right to a nationality is a basic human right, ${ }^{105}$ the structure of evidentiary procedures and local practices can present obstacles to stateless persons in achieving that right. The authority invested in village headmen as customary focal points in the

104 Flaim (n 14) 148.

105 See, eg, Universal Declaration of Human Rights, GA Res 217A (III), UN GAOR, UN Doc A/810 (10 December 1948); Convention on the Rights of the Child, opened for signature 20 November 1989, 1577 UNTS 3 (entered into force 2 September 1990). See also 'Right to a Nationality and Statelessness' Office of the High Commissioner for Human Rights (Web Page) $<$ https://www.ohchr.org/EN/Issues/Pages/Nationality.aspx $>$. 
citizenship application process - and as witnesses in certifying the identity of stateless persons - means that such local figures have significant influence over the success or failure of an application. ${ }^{106}$ This procedure may be considered less bureaucratic and more rooted in local relationships assumed to be authentic, it often induces 'tea money' 107 and exacerbates an individual's vulnerability. As shown in Nida's case, and in Flaim's work, this arrangement depends on how helpful and active a village head is. With the village head's signature counting as a reliable proof, evidence is once again far from being neutrally produced; it is subjected to the relationship between the powerful and the powerless.

\section{StATE IlLEGIBILILTY AND THE FRAMEWORK OF EXCEPTION}

Kamal Sadiq's concept of documentary citizenship ${ }^{108}$ demonstrates that creative solutions through documents in the face of state power are possible. They examine the phenomenon where undocumented migrants are able to falsely acquire documents that confer full citizenship and enable mobility and agency. ${ }^{109}$ One of the conditions that allows for documentary citizenship to be achieved, in this interpretation, is a weak and erratic bureaucracy in a developing nation. ${ }^{110} \mathrm{By}$ contrast, my fieldwork suggests that an erratic bureaucracy is not necessarily a sign of a weak state. Instead, state illegibility expressed through opaque policies and practices can be interpreted as a form of hegemony. I argue that the Thai state performs and normalises its illegibility and consequently justifies its production of arbitrariness through the framework of exception in two ways.

Firstly, the state entitles itself to dictate what could be allowed and exempted from laws without making itself accountable to the law. It can grant citizenship in honour of a special occasion, under an exceptional policy or to an individual whom it judges to have substantially contributed to the nation (what constitutes contribution, again, rests on the judgment of individuals in power). The letter in the beginning of this article is an example of such form of exception. Honouring the king was cited as an occasion to speed up the process of citizenship granting. With opaqueness being a key character of state illegibility, it is also often unclear what truly constitutes a policy and how long the policy lasts. ${ }^{111}$ Must it be a written document? Or do political speeches and people's interactions and experiences with street-level bureaucrats also count? In the case of the Hmong families, could the words and promises given by the officials representing the state considered a policy or were they just empty rhetoric? Can they be held accountable for their promise if one cannot be sure if the uttered words are policies and not individual voices?

106 Flaim (n 14) 155-56; Morlaeku (n 14). Although there is no statute that states a witness in the application process must be a village head, my interviews with informants and the literature above indicate the dependence of stateless persons on such local authorities. See Abigaël Pesses. Highland Birth and Citizenship Registration in Thailand: Final Report on Karen Focus Group Discussions in Chiang Mai Province (Report, United Nations Educational, Scientific and Cultural Organization 17 March 2018) <https://hal.archives-ouvertes.fr/hal01736494/document>.

107 A bribe.

108 Kamal Sadiq, Paper Citizens: How Illegal Immigrants Acquire Citizenship in Developing Countries (Oxford University Press 2009).

109 ibid.

110 ibid 29-30, 117-19, 128, 131, 134.

111 Chris Shore and Susan Wright, Anthropology of Policy: Critical Perspectives on Governance and Power (Routledge 1997) 5. 
Secondly, the state positions citizenship acquired through naturalisation as a less legitimate type than one obtained by Thai nationals at birth. Rather than a natural birthright, citizenship through naturalisation is subject to a state's permission to begin with, and can be revoked at any time, usually in the name of national security. As seen in the Ethnographic Account One, acquired citizenship of villagers was not 'effective' citizenship. Branded as 'unlawful Others', their capturing and punishing evokes a sense a spectacle performed by the state to reestablish

the dissymmetry between the subjects who has dared to violate the law and the allpowerful sovereign who displays his strength ... the punishment is carried out in such a way as to give a spectacle not of measure, but of imbalance and excess. ${ }^{112}$

Despite the opaqueness of the state, I argue that having been subjected to state illegibility all their lives, stateless persons do not necessarily fail to 'read' the state; most anticipate illegible practices by the state and respond through tactics such as keeping track of communications with the state in the case of Hmong family, finding ways to maintain more than one identity such as in Nida's case or engaging in paying the 'tea money' despite meeting the citizenship criteria. ${ }^{113}$ However, on this latter point, after the military toppled the 'corrupted' elected government in 2014, the Thai state declares itself 'intolerant' of such bribery and all kinds of corruption. ${ }^{114}$ Attempting to draw its legitimacy from being transparent and accountable, it flexes its muscles by 'following the rules' and employing harsh measures and fear in its management of the non-citizen 'Other'. Falling into such category, stateless persons are pressured to familiarise themselves with these new rules and mobilise accordingly. Approaching the NHRC and demanding recognition by demonstrating belonging through documentary evidence can be interpreted as one way of responding to state illegibility in the era where the state declares itself to be upholding transparency, human rights and the standardisation of practices. Reading the state is therefore both a skill, and a burden, that stateless persons constantly need to keep up with and modify their responses to fit the state rhetoric.

\section{CONCLUSION}

As argued by Lindsey Kingston, statelessness is not only a cause but a symptom of marginalisation. ${ }^{115}$ In this article, I build on the work of other scholars to reveal a complex and unequal relationship between stateless persons and the state through the concepts of legibility and state illegibility. My ethnographic accounts

112 Michel Foucault, Discipline and Punish: The Birth of the Prison, Alan Sheridan tr (Pantheon Books 1977) 49.

113 Many participants revealed to me that they still had to pay tea money to get faster facilitation or to obtain a signature from a village head in their citizenship application despite fulfilling eligibility criteria.

114 The military government itself has since faced a lot of large-scale corruption scandals. See, eg, 'Rajabhakti Park Scandal a Test for the Government', The Nation (online, 11 November 2015) <https://www.nationthailand.com/opinion/30272722>; Pavin Chachavalpongpun, 'The Latest Thai Corruption Scandal is Causing Problems for the Ruling Junta' The $\begin{array}{lllll}\text { Washington Post } & \text { (online, } 2018 \text { ) }\end{array}$ $<$ https://www.washingtonpost.com/news/democracy-post/wp/2018/01/23/the-latest-thaicorruption-scandal-is-causing-problems-for-the-ruling-junta/>.

115 Lindsey Kingston, 'Worthy of Rights: Statelessness as a Cause and Symptom of Marginalisation' in Tendayi Bloom, Katherine Tonkiss and Phillip Cole (eds), Understanding Statelessness (Routledge 2017) 17. 
affirm existing literature on the myth of complete and even bureaucracy, and further reiterate the circular dynamic of legibility and illegibility. With respect to legibility, the state demands that stateless persons wishing to obtain citizenship be 'legible' through documents. Yet, the state and its administrative bodies' own practices regarding documents are uneven. Through inconsistent rules and policies and selective application of the rules, the state has created a system of governing that on the surface demands clarity but in practice operates under opacity.

In using the theoretical framework of state illegibility and ethnographic accounts, I further illuminate the process by which the state places burden on the stateless. All three accounts demonstrate various forms of state illegibility and how they are justified in the name of national security. Under such pretext, the state exercises the ultimate authority to revoke citizenship en masse, disbelieve the promise and evidence produced by the state itself and disregard documentary mistakes made by representatives of the state. The ethnographies confirm common challenges facing many stateless persons beyond the context of Thailand such as the pattern of legal incoherence, unexpected revocation of rights, reliance on favours from officials and mysterious disappearance of documents into a black hole of the bureaucratic universe. I argue that stateless persons, having been subjected to state illegibility all their lives, are well aware of its various forms and continuously devise means to anticipate and respond to them. This knowledge does not take away the burden placed upon them. Neither does it reduce the danger of the state's rhetoric of standardised and fair bureaucracy.

Therefore, for those working to address statelessness, it is important to recognise and acknowledge various forms of state illegibility. Failure to do so risks reducing statelessness to a legalistic issue to be solved primarily by amending the laws or producing documents. As shown by the ethnographies, this approach risks placing blame on individuals for not possessing the right documents and further exacerbating the vulnerabilities of stateless individuals. Conceptualising unevenness in state bureaucratic practices as state illegibility rather than weak bureaucracy therefore allows us to recognise the violence that is systemic and rooted in discrimination, rather than viewing it as unintentional and anomalous errors. 